\title{
PEMAKNAAN KHALAYAK DAN HEGEMONI MEDIA MENGENAI NASIONALISME DALAM IKLAN \\ (Studi Resepsi pada Iklan Djarum versi Bull Race, Telkomsel versi Halmahera dan You C1000 versi Miss Universe)
}

\author{
Artyasto Jatisidi \\ Fakultas Ilmu Komunikasi Universitas Prof. Dr. Moestopo \\ Email: me@artyasto.com
}

\begin{abstract}
The era of globalization took effect on today's Indonesian nationalism, nationalism of the Indonesian nation is distorted away from its original meaning. The symbols of global cultural products as if drowning sense of all Indonesia's youth. On the other hand the mass media also play a role in this, by creating false consciousness and false about the value of nationalism. One is through advertisements on television.

The theory used in this research is the Reception Analysis Stuart Hall that positioned the audience at the 3 position, Dominant-hegemonic-hegemonic, Negotiation and Opposition. From the results of these positions are expected to be concluded as to what nationalism typical community-owned Indonesia, and the power of the media hegemony. This study used qualitative methods, with a critical paradigm. Then, the data obtained through interviews with the four informants were selected by purposive sampling.

The results showed that the people of Indonesia occupies a tendency on the Negotiation position, they are similar to interpret the ad makers, but they also have alternatives meaning. From the research it can be said that the people of Indonesia has a typical pragmatic nationalism that sees nationalism in terms of togetherness.
\end{abstract}

Keywords : Meaning, Nasionalism, Hegemony, Culture, Advertising

\section{PENDAHULUAN}

Kata nasionalisme menurut Kamus Besar Bahasa Indonesia, adalah suatu paham (ajaran) untuk mencintai bangsa dan negaranya sendiri.Namun seiring dengan perkembangan zaman, jiwa nasionalisme mengalami distorsi yang teramat jauh dari makna aslinya. Kata nasionalisme hanya slogan yang menghiasi tema-tema seminar dan pamflet-pamflet serta spanduk-spanduk di jalan raya.

Roh nasionalisme hilang secara perlahan terkikis oleh era globalisasi.
Bangsa ini menjadi bangsa yang lemah dan merasa malu untuk menjadi bangsa Indonesia. Disadari atau tidak hal inilah yang memperlambat kemajuan negara kita. Nasionalisme telah luntur dalam simbol-simbol semu, dan tidak lagi menjadi falsafah hidup.

Ironisnya, di tengah gelombang globalisasi yang menuntut kesiapan kultural, masyarakat justru terkondisikan dalam sebuah paradoks: Seharusnya masyarakat mampu mengendalikan gerak 
globalisasi, namun ternyata malah ikut terbawa arus. Konsekuensinya, kebanggaan untuk menghayati nilai-nilai kebangsaan diam-diam mengalami kemerosotan tajam atau anjlok hingga titik nadzir. (Soekarwo, dalam Suhartoko, 2012:III).

Ketika simbol-simbol kebangsaan tergerus oleh maraknya simbol-simbol sosial, maka peradaban kawula muda pun kian samar. Tidak jelas lagi batasan atau rambu-rambu budaya bangsa yang dulu dikenal adiluhung, mana budaya asing yang berpotensi membuat kawula muda tercerabut dari akar budaya bangsanya.

Banyaknya kawula muda yang mulai kehilangan identitas diri karena gempuran budaya asing merupakan fenomena yang tak diragukan lagi. Demikian juga banyaknya anak muda yang tidak lagi mengenal pilar-pilar kebangsaan, merupakan fakta yang tak terbantahkan. Bahkan, tidak jarang ditemui anak muda yang mulai 'lupa' mengurutkan sila-sila dalam Pancasila. Padahal, Pancasila merupakan dasar negara Repubik Indonesia, yang bagi warga negaranya mestinya tidak hanya dihafal urutan kelima silanya, tetapi menjadi landasan hidup bermasyarakat dan bernegara. (Suhartoko, 2012:X)

Tetapi, fakta menunjukkan lain. Di tengah hegemoni budaya global yang berlangsung begitu cepat,banyak kawula muda yang seolah-olah kehilangan rasa keIndonesia-annya, kehilangan nasionalismenya. Simbol-simbol sosial produk budaya global seakan menenggelamkan rasa ke-Indonesia-an mereka. (Suhartoko, 2012:XI)

Lebih lagi sistem demokraksi yang diterapkan tidak serta merta membebaskan Bangsa Indonesia dari berbagai masalah.
Keinginan publik agar dilakukan reformasi total terhadap birokrasi pemerintahan yang selama ini dinilai sangat korup, gagal diwujudkan. Kondisi ini secara langsung atau tidak langsung berdampak pada melemahnya Nasionalisme Indonesia di kalangan rakyat.(Thung Ju Lan dan M. Azzam, 2011:1-2)

Konsep hegemoni (dominasi kekuasaan) sering digunakan oleh sosiolog untuk menjelaskan fenomena terjadinya usaha untuk mempertahankan kekuasaan oleh pihak penguasa. Penguasa di sini dalam arti luas, tidak hanya terbatas pada penguasa negara (pemerintah).

Menurut Burton, hegemoni adalah tentang cara menerapkan kekuasaan ideologi yang tidak terlihat. Hegemoni adalah tentang proses-proses yang melaluinya seperangkat ide milik satu kelompok sosial menjadi dominan dalam suatu masyarakat. Media massa mengungkapkan kekuasaannya dengan menciptakan ide yang palsu tentang berbagai nilai dan hubungan sosial, sehingga apa yang kita kira tahu sebagai benar adalah angan-angan pandangan tentang dunia adalah banyak dibentuk melalui media massa. (Burton, 1999:96)

Hariyono memandang bahwa iklan terkini semakin canggih untuk mengkonstruksi kesadaran palsu kepada khalayak, dalam hal ini media massa berusaha untuk mempengaruhi khalayak dan menanamkan realitas palsu, sehingga mereka meyakini wacana media dianggap sebagai suatu hal yang wajar.

Memang di era reformasi kehidupan riil masyarakat banyak dipengaruhi oleh sistem kapitalis. Tatanan hidup kapitalis yang cenderung menekankan reifikasi (proses pembedaan) 
menciptakan pendangkalan nilai-nilai kehidupan. Mantera untuk peningkatan daya beli lebih ditonjolkan daripada peningkatan daya hidup. Masyarakat direkayasa untuk lebih mengutamakan kehidupan ekonomi yang impersonal dan sempit dengan berbagai iklan yang canggih dalam mengkonstruksi kesadaran palsu. (Hariyono:2014:17)

Nasionalisme dalam iklan pun sering muncul di stasiun TV di Indonesia beberapa tahun belakangan ini. Salah satunyaadalah iklan Djarum versi Bull Race, Telkomsel versi Halmahera danYou C 1000versi Miss Universe, menggunakan temanasionalisme dalam iklan namun semu. Iklan tersebut ditampilkan sebagai penggugah nasionalisme khalayak, namun tidak dikemas dengan kemurnian jiwa keindonesiaan. Iklan-iklan ini mengangkat tema etnisitas namun di sisi lain ada hal-hal yang kontradiktif, yaitu dari sisi penggunaan latar belakang musik asing dan penggunaan ikon-ikon global. Iklan-iklan ini mencoba untuk mencairkan kekentalan nasionalisme etnisitas dengan memasukkan unsur-unsur global dalam tampilan etnis. Ada sebuah upaya untuk mencairkan kekentalan etnisitas dengan cara mengkombinasikan antara visualisasi etnisitas dengan ikon-ikon global yang dilakukan lewat hegemoni media.

Di era globalisasi, informasi berlangsung sangat cepat. Generasi muda cenderung direkayasa menjadi generasi penonton dan konsumen. Media massa elektronik memberi tawaran hiburan 24 jam dengan diselingi iklan yang memikat. Konsekuensinya, berbagai pengaruh asing, baik yang positif dan negatif dengan cepat dan massif berdatangan. Ironisnya sebagian besar perilaku manusia lebih banyak ditentukan oleh pengaruh bawah sadar. (Hariyono:2014:173)

Hal yang menarik selanjutnya untuk dikaji bagaimana fenomena iklan ini dimaknai oleh khalayak. Dengan latar belakang yang berbeda-beda mulai dari sosial, budaya, historikal yang mempengaruhi pemaknaan mereka terhadap nasionalisme dalam iklan. Di era globalisasi, khalayak kekinian lebih aktif dalam memaknai iklan yang disajikan oleh pembuat iklan. Dengan pola berpikir yang mereka miliki mereka cenderung mengkritisi iklan yang disajikan. Selain itu hal yang menarik lainnya untuk dikaji adalah berdasarkan posisi-posisi pemaknaan khalayak tersebut, peneliti dapat menentukan sejauh mana hegemoni media dalam menghegemoni khalayak.

Unsur nasionalisme dalam iklan yang muncul di stasiun TV di Indonesia beberapa waktu belakangan ini seolah menjadi penggugah rasa nasionalisme khalayak. Salah satu iklannya adalah Djarum versi Bull Race, Telkomsel versi Halmahera danYou C1000 versi Miss Universe, mengambil nasionalisme dalam iklan yang sarat akan unsur-unsur keindonesiaan namun semu. Iklan tersebut ditampilkan sebagai penggugah nasionalisme khalayak, namun tidak dikemas dengan kemurnian jiwa keindonesiaan.

Pada Teori Pemaknaan (Reception Theory) yang di gagas oleh Stuart Hall, mengatakan bahwa makna yang dimaksudkan dan yang diartikan dalam sebuah pesan bisa mungkin berbeda. Dalam hal ini berarti bahwa penonton juga memiliki interpretasi atau memiliki nilai makna terhadap apa yang digambarkan oleh televisi. Latar belakang di atas 
menunjukkan bahwa ternyata meski media dominan bisa menanamkan tetapi khalayak juga bisa terus secara aktif memberikan makna tertentu.

Stuart Hall menyebutnya sebagai proses encoding-decoding. Pemaknaan khalayak tersebut bisa dipengaruhi oleh berbagai faktor, mulai dari aspek sosial, aspek budaya, aspek historikal Selanjutnya Stuart Hall mengutarakan bahwa ketika khalayak memaknai suatu pesan (decoding), terdapat tiga posisi yaitu :Dominant-hegemonicposition, Negotiatedposition, Oppositionalposition.

Selanjutnya, menjadi hal yang menarik untuk dikaji yaitu, apakah iklan tersebut berhasil untuk menghegemoni khalayak? Apakah iklan tersebut mampu memperlihatkan cerminan mengenai Indonesia pada semua khalayak? Bagaimana nasionalisme dalam iklan dimaknai oleh khalayak, bagaimana aspek sosial, aspek budaya, aspek historikal mempengaruhi pandangan seseorang terhadap nasionalisme dalam iklan?

Semua pertanyaan tersebut peneliti rangkum dalam kalimat "Sebuah penelitian mengenai nasionalisme Indonesia dalam iklan, bagaimana posisi pemaknaan khalayak terhadap iklan tersebut, serta bagaimana kekuatan hegemoni media melalui iklan dengan unsur nasionalisme."

Dengan latar belakang masalah di atas, maka peneliti mengambil judul penelitian "Pemaknaan Khalayak Dan Hegemoni Media Mengenai Nasionalisme Dalam Iklan (Studi Resepsi pada Djarum versi Bull Race, Telkomsel versi Halmahera dan You C 1000 versi Miss Universe)". Dan berikut adalah poin-poin identifikasi masalah dari penelitian ini:
1. Bagaimana khalayak memaknai nasionalisme dalam iklan Djarum versi Bull Race, Telkomsel versi Cerita dari Halmahera danYou C1000 versi Miss Universe? Terutama kaitannya dengan sosial, budaya, maupun historikal yang melatar belakangi khalayak dalam memaknai unsur nasionalisme.

2. Bagaimana posisi-posisi pembacaan khalayak (Sesuai dengan Teori Resepsi Stuart Hall: Dominant-hegemonichegemonic, Negotiated, atau Opposition) pada wacana iklan tersebut?

3. Bagaimana kekuatan hegemoni media melalui iklan dengan unsur nasionalisme tersebut?

Sehingga penelitian ini memiliki tujuan untuk mengetahui apa yang khalayak maknai mengenai nasionalisme dalam iklan-iklan tersebut, terutama kaitannya dengan sosial, budaya, psikologi sosial, maupun historikal yang melatar belakangi khalayak dalam memaknai unsur nasionalisme dalam iklan; untuk mengetahui posisi-posisi pembacaan khalayak (Dominant-hegemonic, Negotiated, atau Opposition) pada wacana iklan tersebut; dan untuk mengetahui sekuat apa hegemoni media melalui iklan tersebut dalam menghegemoni khalayak.

\section{TINJAUAN PUSTAKA}

\section{Iklan dan Pendekatan Budaya dalam Iklan}

Iklan memberikan kepada kita sebuah gambaran tentang proses komunikasi. Sebuah iklan dibentuk oleh dua unsur utama, yaitu pembuat iklan(produsen) dan media massa yang menampilkan iklan. Di dalam iklan terdapat berbagai pengetahuan tentang makna, nilai- 
nilai, ideologi, kebudayaan dan sebagainya. Dalam kaitannya dengan nilai - nilai budaya, iklan sebagai salah satu bentuk komunikasi massa merupakan agen penyebar nilai-nilai budaya dalam masyarakat. Dalam banyak hal, nilai budaya yang terekspresikan dalam iklan sering menjadi acuan perilaku bagi sebagian masyarakat. Dalam konteks ini nilai-nilai budaya dalam iklan dipandang sebagai suatu bentuk yang sengaja ditransformasikan kepada masyarakat sebagai target penyebaran budaya massa. (Rajiyem dan Widodo Agus Setianto, 2004: 155-156).

Pada intinya, dalam dunia periklanan, nilai-nilai budaya juga menjadi salah satu elemen yang digunakan untuk materi periklanan yang secara sengaja ditransformasikan kepada masyarakat sebagai target sebagai upaya mempengaruhi konsumen untuk bertindak sebagaimana yang diharapkan oleh produsen atau perencana iklan.

\section{Transformasi Iklan dan Transmisi Budaya dalam Iklan}

Strategi periklanan akan sukses dijalankan jika para pembuat iklan berpegang pada budaya di mana produk itu akan dipasarkan. Setiap negara memiliki karakteristik budaya masing-masing yang unik, dan budaya ini dapat mempengaruhi kebutuhan serta keinginan konsumen. Karena itu, iklan akan menunjukkan metode dan pesan sebagai respons terhadap kondisi budaya setempat (Frith \& Mueller, 2003:28)

Pendekatan budaya ini pula yang membuat sebuah produk semakin dekat dengan masyarakat dengan cara mengikutsertakan simbol-simbol sebagai representasi dari identitas masyarakat setempat. Simbol tersebut bisa meliputi kebiasaan, kepercayaan religi, cara berkomunikasi(termasuk bahasa di dalamnya), atau ideologi. (Yadi Supriadi, 2013:55).

Karena norma, adat, dan ideologi masyarakat dipandang sangat penting sebagai sebuah strategi periklanan, pengetahuan para kreator iklan tentang budaya menjadi modal utama. Studi lapangan mengenai kondisi lingkungan, aspek sosial politik, serta budaya juga sangat membantu kreator iklan dalam membuat daya tarik konsumen. Melalui ide-ide budaya, iklan dibentuk sebagai alat promosi dan representasi dengan memberikan gambaran tentang frame of reference masyarakat setempat. (Yadi Supriadi, 2013:56).

Intinya, salah satu strategi yang jitu untuk menarik perhatian konsumen adalah dengan menggunakan pendekatan budaya, karena dengan pendekatan ini dapat menjadikan sebuah produk menjadi lebih dekat dengan masyarakat, yaitu dengan cara mengikut sertakan simbol-simbol sebagai bagian dari identitas masyarakat setempat.

\section{Cultural Studies}

Cultural studies atau kajian budaya merupakan suatu bentuk pendekatan dalam kajian komunikasi yang melihat bagaimana cara-cara budaya diproduksi melalui pertarungan diantara ideologi-ideologi yang ada. Istilah ini awalnya muncul dari para teoretisi yang berkecimpung dalam Centre for Contemporary Cultural Studies di Universitas Birmingham. Tradisi ini diawali oleh Richard Hoggart dan Raymond William pada tahun 1950an. Teoretesi yang paling terkenal dalam ranah kajian budaya saat ini adalah Stuart Hall. Hall 
meyakini bahwa media massa berusaha mempertahankan dominasinya melalui kekuasaan.

Oleh karena itu, studi mengenai komunikasi massa menjadi pusat dari kajian budaya yang melihat media sebagai alat kuat dalam pembentukan ideologi. Media memiliki potensi untuk meningkatkan kesadaran masyarakat mengenai isu tentang kelas, kekuasaan, dan dominasi (Littlejohn, 2002: 217).

Penelitian ini menggunakan perspektif cultural studies dengan pertimbangan bahwa iklan dengan unsur budaya yang dapat mengusung pesan ideologis dan menimbulkan pembacaan/pemaknaan tertentu dari audiensnya. Dalam perspektif ini, meskipun media memiliki relasi dengan ideologi dan kekuasaan serta kemampuan menciptakan konsensus bersama, namun Hall berpendapat bahwa penafsiran akan teks media pada dasarnya selalu terjadi melalui hasil pertarungan melawan ideologi. Audiens aktif menggunakan kategorikategori tersendiri dalam membaca pesan media, bahkan menginterpretasikan kembali pesan media tersebut secara bertolak belakang dengan apa yang diinginkan oleh pembuat pesan.

Kehadiran studi resepsi dalam penelitian komunikasi massa, merujuk pada penelitian Stuart Hall (pada tahun 1974) yaitu Encoding and Decodingin the Television Discourse, Hall menggunakan Teori Semiotik Prancis untuk membuktikan bahwa, konten media terdiri atas tandatanda yang terstruktur secara spesifik dan untuk memahami sebuah konten media, audiens harus mampu untuk menerjemahkan tanda-tanda beserta strukturnya (Baran \& Davis, 2000: 262).

\section{Studi Resepsi Model Encoding-Decoding}

Terdapat tiga model yang menjelaskan bagaimana kemungkinan khalayak melakukan decoding terhadap pesan yang dikonsumsinya. Produseniklan (pembuat pesan) mengemas (encoding) makna dengan cara tertentu dengan maksud agar dapat diinterpretasi dengan cara tertentu pula.

1. Dominant-hegemonicreading adalah model dimana khalayak melakukan interpretasi sesuai dengan apa yang diinginkan oleh pembuat pesan. Artinya adalah ketika pembuat pesan menggunakan kode-kode yang bisa diterima umum dan pembaca akan menafsirkan dan membaca pesan tersebut dengan pesan yang sudah diterima umum. Dalam hal inidapat dikatakan tidak terjadi perbedaan penafsiran antara produsen pesan dan pembaca.

2. Negotiated reading adalah model dimana khalayak memahami interpretasi yang diinginkan produsen pesan secara kabur dan menegosiasikan makna dengan elemen extratekstual. Disini khalayak mempunyai alternatif interpretasi, karena mereka bisa saja salah meninterpretasikan atau tidak setuju dengan beberapa aspek yang dimaksudkan produsen pesan.

3. Opositional reading adalah model dimana khalayak memahami interpretasi yang diinginkan produsen pesan namun setelah membandingkan teks dengan sumber-sumber extratekstual, khalayak membentuk makna yang bertentangan dengan yang dimaksudkan oleh produser pesan. Khalayak mengembangkan interpretasi yang berbeda sama sekali 
dengan Dominant-hegemonic reading. Pembacaan oposisi ini muncul ketika pembuat pesan tidak menggunakan kerangka acuan budaya atau keyakinan politik khalayak pembacanya sehingga pembaca akan menggunakan kerangka budaya atau politik sendiri.

Pembacaan khalayak mengenai wacana yang disajikan oleh media sangat mungkin berbeda, hal ini didasari oleh banyak latar belakang, misalnya adalah aspek sosial, budaya, maupun historikal yang mempengaruhi pembacaan tersebut.

\section{Nasionalisme}

Nasionalisme dalam arti umum memiliki definisi suatu paham mengenai nation/bangsa yang dimiliki oleh penduduk/masyarakat di suatu negara. Sementara itu menurut Kamus Besar Bahasa Indonesia, kata nasionalisme memiliki arti paham (ajaran) untuk mencintai bangsa dan negara sendiri. Arti lainnya adalah kesadaran keanggotaan dalam suatu bangsa yang secara potensial atau aktual bersama-sama mencapai, mempertahankan, dan mengabadikan identitas, integritas, kemakmuran, dan kekuatan bangsa itu; semangat kebangsaan. Seperti yang diutarakan oleh M'Azzam Manan dan Thung Ju Lan(2011:8) dalam bukunya,

Nasionalisme merefleksikan sejarah masa lalu, khususnya menyakut kisah perjalanan hidup atau proses terbentuknya suatu bangsa yang disebut nasion. Aspek historis yang dikandungnya menyebabkan nasionalisme setiap bangsa. Tidak saja bagi orang-orang pada satu generasi yang berada di negara-negara yang berbeda, tetapi juga bagi generasi yang berbeda di satu Negara yang sama.
Sementara itu Azyumardi Azra, membagi nasionalisme menjadi beberapa bagian yaitu, nasionalisme politik, nasionalisme ekonomi, nasionalisme agama, dan nasionalisme. (Azyumardi Azra. Dalam M'Azzam Manan dan Thung Ju Lan, 2011:10)

\section{Nasionalisme Indonesia}

Mengutip pernyataaan dari Assy'ad mengenai nasionalisme Indonesia saat ini, ada hal yang patut untuk disayangkan bahwa nasionalisme saat ini mengalami kemunduran,

Berbagai masalah kini dihadapi oleh bangsa Indonesia; mulai meroketnya angka kemiskinan, penumpukan pengangguran, terorisme, gesekan horizontal antarkelompok masyarakat, korupsi yang melibatkan para pejabat dan birokrat lintas sektoral, juga krisis multidimensi, serta tergerusnya kepercayaan kepada para pemimpin dan lain sebagainya. Hal itu berimbas pada deretan masalah yang kian panjang dan berpotensi mengikis rasa nasionalisme di kalangan masyarakat. Padahal rasa nasionalisme itu penting dimiliki sebagai modal untuk bisa menjadi bangsa yang maju, aman, damai, adil dan sejahtera. Karena itu, di tengah himpitan berbagai masalah tersebut, masing-masing komponen bangsa ini perlu introspeksi. Di antaranya menempatkan persatuan dan kesatuan, kepentingan dan keselamatan bangsa dan Negara di atas kepentingan pribadi atau golongan. Sikap rela berkorban demi kepentingan bangsa dan negara juga perlu dikembangkan untuk menumbuhkan kebaggaan sebagai bangsa Indonesia dan bertanah air Indonesia, tidak rendah diri di tengah pergaulan dengan bangsa-bangsa di 
dunia" (Muhamad Assy'ad dalam Suhartoko, 2012:31-32)

Oleh karena itu, gambaran masalah yang telah disebutkan diatas yang dihadapi oleh masyarakat indonesia dapat berimbas pada deretan masalah yang kian panjang dan berpotensi mengikis rasa nasionalisme di kalangan masyarakat.

\section{Nasionalisme dalam Arti Sempit}

Lind (1994:87-88) mengemukakan tentang nasionalisme il-liberal, yaitu nasionalisme yang dikembangkan berdasarkan garis agama, atau etnis, seperti di Iran, Pakitsan, India, dan lain-lain.

Hall (1993: 1-2) menjelaskan tentang nasionalisme integratif, yaitu nasionalisme yang berkembang karena memanfaatkan rasa dendam karena ditindas bangsa lain. Nasionalisme ini mendorong integrasi seluruh aspek kehidupan bangsa dalam rangka menghadapi bangsa-bangsa lain yang menindas. Contoh nasionalisme seperti ini dikembangkan kaum Fascisme Italia, Chauvinisme (Ultra-nasionalisme) di Jepang, dan Naziisme di Jerman.

Disamping itu ada pula Keating (2001:179) yang mengutarakan tentang ethnic nationalism, dalam gagasan ethnic nationalism, sebuah bangunan sosial, politik, maupun budaya cenderung dibangun atas sifat kelompok etnis yang dominan. Asumsi ini muncul karena pada dasarnya ethnic nationalism dipengaruhi oleh adanya pengaruh kolonialisme internal yang menimbulkan ketimpangan regional dan spasial serta relative deprivation yang dimarjinalkan. Lalu menurut Karl Cordell (2016:307) Reaksi yang sering muncul pada ethnic nationalism adalah salah satunya ke arah ide ultranasionalis, kadang-kadang ditujukan kepada masyarakat minoritas bawahan. Ethnic nationalism secara eksplisit cenderung kuat, sebagian besar pihak-pihak yang ultra nasionalis menggunakan "kartu etnik" dalam bentuk ide etno-nasionalis sebagian besar untuk memicu kekhawatiran masyarakat terhadap multikulturalisme.

\section{Nasionalisme dalam Arti Luas}

Lind (1994:87-88) mengemukakan tentang nasionalisme liberal, yaitu nasionalisme yang menjunjung tinggi kebebasan individual dalam suatu negara bangsa yang berlandaskan konstitusi modern.

Sedangkan Hall (1993:1-2) pun menyebutkan tentang Nasionalisme resorgimento, yaitu yaitu nasionalisme yang muncul dari bawah. Nasionalisme ini umumnya dipelopori oleh para cendikiawan yang jumlahnya bertambah banyak karena pendidikan. Para terpelajar ini sebagai orang-orang modernis, liberal dan demokrat mendorong terbentuknya integrasi normative dalam teritorial mereka sebagai negara bangsa (nation state) yang liberal dan demokratis. Faktor lain yang mendorongnya adalah perkembangan ekonomi dari masyarakat agraris ke masyarakat industrial, dari pedesaan ke perkotaan karena proses industrialisasi. Tipe ini berkembang di Eropa pada abad ke18 - 19.

Lalu menurut Keating (2001:179) ia mengemukakan tentang civic nationalism (nasionalisme kewargaan). Nasionalisme kewargaan menciptakan adanya proses interaksi sosial \& poliltik pada berbagai tingkat yang membuka peluang bagi adanya pertukaran sosial dan politik maupun budaya antar masyarakat yang berasal dari latar belakang etnis, agama, komunitas 
yang beragam untuk kemudian berbagi komitmen dalam rangka mengembangkan konstitusi, aturan, konsensus, kesepakatan bersama yang lebih umum dan bersifat lintas-basis primordial.

Lalu Stout (2004:291) mencoba menggambarkan perekat yang merangkul warga secara bersama-sama, dalam tradisi pragmatis dari filsuf lama seperti Dewey dan lebih yang kontemporer seperti Rebecca Chopp: "Konsepsi civic nationalism adalah pragmatis dalam arti bahwa ia berfokus pada kegiatan yang diadakan secara umum adalah sebagai pokok dari masyarakat... mereka adalah kegiatan di mana ikatan normatif disematkan serta dibicarakan".

\section{Hegemoni}

Istilah hegemoni berasal dari istilah Yunani, Hegeisthai (to lead). Konsep ini banyak digunakan oleh sosiolog untuk menjelaskan fenomena terjadinya usaha untuk mempertahankan kekuasaan oleh pihak penguasa. Penguasa disini memiliki arti luas, tidak hanya terbatas pada penguasa negara (pemerintah). Hegemoni bisa didefinisikan sebagai: dominasi oleh satu kelompok terhadap kelompok lainnya, dengan atau tanpa ancaman kekerasan, sehingga ide-ide yang didiktekan oleh kelompok dominan terhadap kelompok yang didominasi diterima sebagai sesuatu yang wajar (common sense).

Hegemoni adalah tentang cara menerapkan kekuasaan ideologi yang tidak terlihat. Hegemoni adalah tentang prosesproses yang melaluinya seperangkat ide milik satu kelompok sosial menjadi dominan dalam suatu masyarakat(Burton, 1999:96).

Gramsci (1891-1937) merupakan tokoh yang terkenal dengan analisa hegemoninya.
Analisa Gramsci merupakan usaha perbaikan terhadap konsep determinisme ekonomi dan dialektika sejarah Karl Marx. Gramsci mengeluarkan argumen bahwa kegagalan tersebut disebabkan oleh ideologi, nilai, kesadaran diri, dan organisasi kaum buruh tenggelam oleh hegemoni kaum penguasa (borjuis). Hegemoni ini terjadi melalui media massa, budaya pop, sekolah-sekolah, bahkan melalui khotbah atau dakwah kaum religius, yang melakukan indoktrinasi sehingga menimbulkan kesadaran baru bagi kaum buruh.

Media mengungkapkan kekuasaannya dengan menciptakan ide yang palsu tentang berbagai nilai dan hubungan sosial, sehingga apa yang kita kira tahu sebagai benar adalah angan-angan pandangan dunia tentang banyak dibentuk melalui media. (Burton, 1999:96)

Bisnis melalui media telah membuat pesona pada produk industri, yang meskipun diperlukan, tetapi demi image kebahagiaan yang diciptakan dalam kehidupan di media, produk tersebut harus dimiliki. Gaya hidup yang dipertontonkan melalui media, menjadi cita-cita setiap orang. Sehingga media menjadi sarana yang sangat efektf dalam membentuk selera masyarakat. Dalam kondisi demikian, kebudayaan yang berkembang di media adalah kebudayaan instan yang selalu ada kaitannya dengan kepentingan bisnis. (Wibowo, 2007:34)

Prinsip-prinsip yang menonjol dalam hiburan adalah kesenangan yang tertanam dan menjelma dalam kehidupan manusia, sehingga pada saat lain akan menjelma membentuk budaya manusia. Dalam dunia seperti ini, hiburan dan 
bahkan budaya telah menjelma menjadi industri (Burhan Bungin, 2001; 63).

Pada konteks ini, Theodor Adorno dan Max Horkheimer mengatakan, budaya industri adalah media tipuan. Budaya telah berubah menjadi alat industri serta menjadi produk standar ekonomi kapitalis. Dunia hiburan telah menjadi sebuah proses reproduksi kepuasan manusia dalam media tipuan. Hampir tidak ada perbedaan lagi antara kehidupan nyata dan dunia yang digambarkan dalam film yang dirancang menggunakan efek suara dengan tingkat ilusi yang sempurna sehingga tak terkesan imaginator. (Simon During, 1993; 31)

Kaitannya dengan penelitian ini, penelitian ini meneliti sekuat apa hegemoni media dalam menghegemoni khalayak dengan wacana iklan yang mengangkat nasionalisme Indonesia.

\section{METODE PENELITIAN}

Penelitian ini menggunakan paradigma kritis, artinya adalah bahwa objek atau realitas sosial yang selama diamati merupakan penampakan realitas yang tidak nyata atau semu. Sedangkan realitas objektif yang sebenarnya itu diabaikan. Oleh karena itu, penelitian dengan paradigma kritis memiliki tujuan untuk membentuk suatu kesadaran sosial kepada khalayak agar lebih kritis dan dapat melihat realitas yang sebenarnya.

Menurut Poerwandari (2001:17), manusia dihadapkan dengan kondisi sosial, ekonomi dan politik yang mempengaruhi kehidupan mereka dalam setiap kegiatannya. Posisi individu dan kelompok dalam lingkungan sosial akan berbedabeda, sehingga manusia memiliki kemampuan untuk menciptakan atau mengubah arti dari kehidupan yang dialaminya. Dengan demikian, paradigma kritis akan melihat ilmu sebagai sesuatu yang tidak terpisahkan dari nilai-nilai yang hidup dalam masyarakat.

Dalam penelitian kualitatif, posisi informan adalah sangat penting, karena dia merupakan sumber data yang utama bagi peneliti. Selain itu, informan juga berlaku sebagai pemberi definisi tentang realitas sosial.

Penelitian ini memakai analisis resepsi yang pada hakekatnya mencoba untuk melihat penerimaan khalayak sebagai target audiens dari suatu media. Karena itu, interpretasi dari khalayak akan menjadi hal yang sangat utama. Khalayak dalam analisis resepsi disebut juga sebagai komunitas interpretative, pengertiannya adalah sekumpulan khalayak yang akan memaknai tayangan-tayangan tersebut. Tetapi dalam melakukan penelitian ini, peneliti memilih informan berdasarkan purposive sampling, yaitu teknik pengambilan sampel tidak secara acak, tetapi dipilih dengan sengaja pada informan yang memenuhi kriteria sesuai dengan kebijaksanaan peneliti (Patton, 2002:243).

Peneliti menerapkan beberapa kriteria pemilihan informan, kemudian peneliti memilih informan-informan yang peneliti anggap dapat memberikan informasi yang mendalam dan komprehensif mengenai topik penelitian yang peneliti sedang lakukan.

\section{HASIL PENELITIAN DAN PEMBAHASAN}

\section{Analisis Resepsi Nasionalisme}

Dari hasil wawancara peneliti bisa menganalisa bahwa masing-masing informan mempunyai pemaknaan terhadap iklan tersebut. Menurut analisis resepsi 
Stuart Hall ada tiga posisi pemaknaan atau decoding, yaitu pemaknaan dominanhegemonik, pemaknaan negosiasi dan pemaknaan oposisi

\section{Dominan-Hegemonik}

Posisi pemaknaan dominan-hegemonik adalah pemaknaan dimana khalayak mengartikan dan membaca makna yang sesuai dengan makna yang ingin disampaikan oleh si pembuat iklan atau produsen.

Dalam hal ini pembuat iklan ingin menyampaikan bahwa nasionalisme adalah iklan yang menampilkan budaya dan keindahan Indonesia. Sehingga rasa cinta tanah air bisa terbangun dengan melihat iklan tersebut.

Informan yang memilih pemaknaan dominan-hegemonik adalah informan Sony, dari jawaban-jawaban yang disampaikan saat wawancara terlihat bahwa iklan dengan topik nasionalis budaya mampu membuat seseorang tumbuh rasa nasionalismenya. Selain itu menurut informan Sony iklaniklan tersebut sesuai dengan pengetahuan yang diterimanya bahwa Indonesia seperti yang digambarkan dalam iklan tersebut itu mampu menimbulkan rasa cinta tanah air, dari iklan-iklan tersebut ingin merangkul anak muda dengan tetap mengikuti tradisi dan anak muda dalam iklan-iklan tersebut melakukan dengan caranya yaitu dengan sedikit improvisasi artinya budaya-budaya itu tidak konvensional, bisa mengikuti jaman. Lalu, hal yang menyebabkan Indonesia terpuruk adalah kesalahan para pemimpinnya dalam mengelola bangsa dan kekayaan alam, dari salah satu faktor inilah pembuat iklan mengangkat topik nasionalisme.

\section{Negosiasi}

Jawaban-jawaban wawancara yang disampaikan oleh informan Irwan dan Rocky masuk ke dalam pemaknaan negosiasi. Artinya informan menyetujui tentang apa yang ingin disampaikan pembuat iklan yaitu menanamkan dan mengembangkan rasa nasionalisme, tapi tidak sepenuhnya semakna dengan pembuat iklan disini informan berpendapat bahwa topik nasionalis budaya bukan hanya tentang budaya dan alam atau tentang kondisi nasionalisme yang sedang terpuruk sehingga ingin membangkitkan rasa nasionalisme.

Tetapi, Informan-informan di sini melihat bahwa topik nasionalisme yang ditampilkan hanya trend sesaat, yang menarik para produsen untuk membuatnya diharapkan khalayak terpikat untuk melihat dan membeli produk yang diiklankan. Karena iklan terlihat kontradiktif, informan Rocky melihat dari sisi musik latar yang digunakan pada iklan, yang sebetulnya tidak langsung menumbuhkan rasa nasionalisme karena menggunakan lagu berbahasa Inggris. Dalam hal ini juga pandangan informan mengenai faktor yang menjadi alasan pembuat iklan mengangkat topik nasionalisme selain dari semakin semu-nya rasa nasionalisme, informan melihat rasa nasionalisme kekinian itu cenderung bergeser kearah pragmatis yaitu nasionalisme didefinisikan sebagai rasa kebersamaan mempersatukan rakyat Indonesia. Tetapi tetap mereka juga memiliki pandangan bahwa iklan-iklan ini sebenarnya masih terasa untuk promosi produknya. Terutama untuk iklan You C1000 cenderung kurang bekorelasi antara minum You C1000 dan nasionalisme. 


\section{Oposisi}

Pemaknaan oposisi adalah pemaknaan yang berlawanan. Artinya adalah pemaknaan yang ditawarkan oleh pembuat iklan berbeda atau berlawanan dengan pemaknaan khalayak.

Yang termasuk dalam pemaknaan oposisi adalah informan Salman, ia berpendapat bahwa dari iklan tersebut tidak mengangkat nasionalisme. Ia hanya menekankan suatu kepentingan bisnis.

Bahkan informan Salman mengatakan bahwa iklan-iklan tersebut memanfaatkan nasionalisme sebagai strategi pemasaran. Menurut informan Salman topik nasionalisme yang diambil hanya sebagai kepentingan produsen karena untuk mengejar keuntungan bisnis. Nasionalisme masyarakat Indonesia diperlihatkan luntur itu karena media ditumpangi oleh kepentingan, tetapi bila dilihat di daerahdaerah terpencil itu rasa nasionalisme itu tetap ada dan tetap dilestarikan masyarakat. Dan dalam hal ini ia juga mengutarakan bahwa yang menjadi salah satu faktor bukanlah krisis nasionalisme, melainkan adalah lokasi yang menjadi target penjualan produk, karena iklan dinilai sebagai upaya untuk mengejar profit karena iklan merupakan mata rantai suatu bisnis.

\section{Tipikal Nasionalisme Indonesia}

Dewasa ini memang ada pergeseran nasionalime dulu dan sekarang, seperti halnya budaya di Indonesia, lagu hiphop bisa saja dikatakan sebagai budaya luar, tapi hiphop ini dijadikan senjata oleh masyarakat Indonesia untuk menyatukan kebersamaan antar sesama, kebersamaan itulah yang disebut nasionalisme. Lalu adegan surfing yang sarat akan budaya asing itu dianggap suatu hal yang wajar, karena kita harus bisa berbaur dengan budaya asing agar orang di luar negeri bisa memiliki pandangan bahwa budaya Indonesia itu juga bisa mengikuti zaman saat ini, sedikit-banyak pasti akan terjadi akulturasi budaya. Bila mengingat sejarah masa lalu ketika jaman penjajahan kita hanya menggunakan bambu runcing untuk senjata. Namun ketika kita mendapatkan peninggalan senjata api dari penjajah, Jendral Sudirman memutuskan untuk menggunakan senjata api peninggalan Belanda dan Jepang tersebut untuk berperang, hal ini bisa dianggap bahwa alat adalah hanya sebuah alat, tetapi bagaimana alat tersebut digunakan sebagai alat untuk memperkuat kebersamaan, itulah nasionalisme. Selanjutnya mengenai bagaimana kebanggan atau kekecewaan informan mengenai nasionalisme Indonesia saat ini, mereka menyatakan bangga terhadap rasa nasionalisme bangsa Indonesia hanya disaat-saat tertentu dan bisa jadi kecewa di saat-saat tertentu, kecewa saat banyak masyarakat yang masih mempermasalahkan kubu Jokowi dan Prabowo, namun muncul rasa bangga ketika masyarakat Indonesia dalam kondisi terancam, mereka dengan mudah dipicu rasa nasionalismenya. Dan sebenarnya pandangan krisis nasionalisme itu hanya ketika kita berada di kota besar yang masyarakatnya bersifat heterogen, karena masyarakat di kota besar yang lebih pluralis. Tetapi bila kita lihat dipelosoknegeri rasa nasionalisme bangsa Indonesia cenderung masih kental dan lestari, karena faktor geografis kita sebagai negara kepulauan untuk mereka yang di daerah terpencil itu cenderung terisolir dari budaya luar. 


\begin{tabular}{|c|c|c|c|c|}
\hline Informan & Posisi & $\begin{array}{l}\text { Tipikal } \\
\text { Ideologi }\end{array}$ & $\begin{array}{l}\text { Tipikal } \\
\text { Nasionalisme }\end{array}$ & Keterangan \\
\hline Sony & $\begin{array}{l}\text { Domin } \\
\text { ant }\end{array}$ & $\begin{array}{l}\text { Budaya } \\
\text { Indonesia } \\
\text { haruslah bisa } \\
\text { mengikuti } \\
\text { zaman yang } \\
\text { terus } \\
\text { berkembang, } \\
\text { sehingga tidak } \\
\text { kelihatan } \\
\text { ketinggalan } \\
\text { jaman dan } \\
\text { anak muda pun } \\
\text { menjadi } \\
\text { bangga dan } \\
\text { semakin } \\
\text { mencintai } \\
\text { Indonesia. }\end{array}$ & Civic Nationalism & $\begin{array}{l}\text { Pekerjaannya sebagai PNS yang sering } \\
\text { ditugaskan ke pelosok Indonesia melihat } \\
\text { bahwa sekarang ini anak muda di pelosok } \\
\text { aktif untuk mempromosikan daerahnya } \\
\text { sebagai upaya daerahnya menjadi destinasi } \\
\text { yang diminati oleh banyak masyarakat. } \\
\text { Ayah beliau menjadi panutan dalam } \\
\text { menjalani hidup, bekerja secara jujur dan } \\
\text { menjauhi sifat tercela } \\
\text { Ia juga menyatakan bahwa pekerjaannya di } \\
\text { bidang teknik infrastruktur adalah } \\
\text { partisipasinya dalam membangun negeri } \\
\text { dan mengembangkan rasa nasionalisme } \\
\text { walaupun hanya skala kecil karena hanya } \\
\text { untuk daerah tertentu di pelosok negeri. }\end{array}$ \\
\hline Informan & Posisi & $\begin{array}{l}\text { Tipikal } \\
\text { Ideologi }\end{array}$ & $\begin{array}{l}\text { Tipikal } \\
\text { Nasionalisme }\end{array}$ & Keterangan \\
\hline Rocky & $\begin{array}{l}\text { Negoti } \\
\text { ated }\end{array}$ & $\begin{array}{l}\text { Memiliki } \\
\text { pandangan } \\
\text { bahwa } \\
\text { nasionalisme } \\
\text { budaya secara } \\
\text { kebersamaan, } \\
\text { di mana ketika } \\
\text { kita mampu } \\
\text { bersama-sama } \\
\text { bercengkrama } \\
\text { antara } \\
\text { masyarakat, } \\
\text { itulah } \\
\text { nasionalisme. }\end{array}$ & Civic Nationalism & $\begin{array}{l}\text { Lahir dan besar dari keluarga yang } \\
\text { harmonis dan selalu menanamkan } \\
\text { kebersamaan terhadap sesama. } \\
\text { Pekerjaannya adalah sebagai dosen. Beliau } \\
\text { menyatakan perwujudan dari rasa cinta } \\
\text { terhadap negeri ini adalah dengan } \\
\text { mengajar mahasiswa dengan baik dan } \\
\text { benar. } \\
\text { Beliau juga merasa kecewa saat batik } \\
\text { diklaim oleh negara tetangga, sejak itu } \\
\text { beliau selalu menggunakan batik dalam } \\
\text { setiap aktivitasnya sebagai dosen. } \\
\text { Ia berpendapat bahwa ketika suatu } \\
\text { teknologi luar dimanfaatkan masyarakat } \\
\text { lokal untuk membangun kebersamaan, } \\
\text { itulah nasionalisme. }\end{array}$ \\
\hline Informan & Posisi & $\begin{array}{l}\text { Tipikal } \\
\text { Ideologi }\end{array}$ & $\begin{array}{l}\text { Tipikal } \\
\text { Nasionalisme }\end{array}$ & Keterangan \\
\hline Irwan & Negoti & Keberagaman & Civic Nationalism & Irwan memiliki latar belakang budaya \\
\hline
\end{tabular}




\begin{tabular}{|c|c|c|c|c|}
\hline & ated & $\begin{array}{l}\text { budaya } \\
\text { Indonesia } \\
\text { perlu } \\
\text { dilestarikan } \\
\text { dengan cara } \\
\text { yang modern, } \\
\text { kita tidak } \\
\text { boleh tertutup } \\
\text { dengan budaya } \\
\text { luar, karena } \\
\text { sebenarnya } \\
\text { kita bisa } \\
\text { mengambil sisi } \\
\text { positif yaitu } \\
\text { semakin } \\
\text { beragamnya } \\
\text { budaya kita. }\end{array}$ & & $\begin{array}{l}\text { padang yang cukup kental namun ketika ia } \\
\text { menikah dengan wanita beretnis tionghoa, } \\
\text { ia ikut berbaur dan juga ikut merayakan } \\
\text { hari raya dalam Tradisi Tionghoa Beliau } \\
\text { juga memandang bahwa kontrak-kontrak } \\
\text { kerjasama dengan negara asing tidak } \\
\text { menodai rasa nasionalismenya, karena dari } \\
\text { sisi positif kita bisa bertukar teknologi } \\
\text { maupun ilmu dengan negeri di luar sana, ia } \\
\text { memandang bahwa itu bukan suatu hal } \\
\text { yang buruk. Kecintaannya terhadap negeri } \\
\text { ia lakukan dengan cara taat membayar } \\
\text { pajak dan juga menggunakan produk- } \\
\text { produk dalam negeri. }\end{array}$ \\
\hline Informan & Posisi & $\begin{array}{l}\text { Tipikal } \\
\text { Ideologi }\end{array}$ & $\begin{array}{l}\text { Tipikal } \\
\text { Nasionalisme }\end{array}$ & Keterangan \\
\hline Salman & $\begin{array}{l}\text { Opositi } \\
\text { on }\end{array}$ & $\begin{array}{l}\text { Kota besar } \\
\text { seperti Jakarta } \\
\text { memiliki } \\
\text { kriteria } \\
\text { masyarakat } \\
\text { yang } \\
\text { heterogen. } \\
\text { Akulturasi } \\
\text { budaya dengan } \\
\text { asing } \\
\text { dipandang } \\
\text { sebagai hal } \\
\text { yang positif, } \\
\text { karena kita } \\
\text { bisa berbaur } \\
\text { dengan budaya } \\
\text { luar dan } \\
\text { menjadi negeri } \\
\text { yang bisa } \\
\text { berkompetisi } \\
\text { dengan negeri } \\
\text { lainnya }\end{array}$ & Civic Nationalism & $\begin{array}{l}\text { Salman lahir dan besar di kota yang } \\
\text { memiliki latar budaya yang kental, namun } \\
\text { hal itu mulai bergeser ketika ia hijrah dan } \\
\text { bekerja di Ibukota Jakarta, pemikiran } \\
\text { beliau menjadi lebih terbuka terhadap } \\
\text { budaya luar. Karena ia sering sekali } \\
\text { berhadapan dengan klien dari luar negeri, } \\
\text { akulturasi budaya adalah hal yang wajar, } \\
\text { alasannya agar budaya Indonesia bisa } \\
\text { diterima oleh global. } \\
\text { Namun hal ini hanya terjadi di kota besar } \\
\text { masyarakat yang heterogen, namun ini tak } \\
\text { terjadi di daerah pedesaan karena } \\
\text { masyarakatnya homogen dan budaya lokal } \\
\text { masih lestari, tidak tercampur budaya luar }\end{array}$ \\
\hline
\end{tabular}

Jadi bisa diasumsikan bahwa dari posisi pemaknaan informan mendekati kesamaan tipikal nasionalisme dalam konteks arti yang luas atau civic nationalism yang secara khusus ada pada posisi nasionalis yang pragmatis. Selain itu 
rasa nasionalisme para informan cenderung semu karena memang dunia ini menciptakan kesemuan itu, realitasnya memunculkan kesemuan terutama tidak terlepas dari peran media masa dalam menghegemoni masyarakat. Khalayak bisa saja berbeda jenis politik antara satu dengan yang lain, hal itu yang menciptakan kesemuan, tetapi bisa berubah total pada situasi terancam, misalnya pada saat bom sarinah awal tahun 2016 yang lalu, semua masyarakat bersatu untuk melawan teroris, bisa dikatakan rasa nasionalisme bangsa Indonesia dengan mudah dan secara instan bisa terbangun saat itu.

\section{Hegemoni}

Mengingat masa lalu ketika orde baru yang dipimpin oleh Presiden Soeharto, memang hanya ada 1 media televisi yaitu TVRI, dan itupun mendapat control yang begitu ketat dari penguasa dan menjadi corong untuk melanggengkan kekuasaannya dengan melakukan hegemoni. Seperti pemutaran secara berkala Film perisitwa G 30 S/PKI yang penuh rekayasa dan pembelokan sejarah dan sampai saat ini masih menyisakan pengaruh bagi sebagian masyarakat di Indonesia sehingga sampai sekarang kita mengenal ada organisasi yang menamakan dirinya front anti komunis yang dibentuk secara sukarela oleh masyarakat itu sendiri. Jadi besar kemungkinannya untuk media menghegemoni khalayak salah satunya dari sisi nasionalisme masyarakat Indonesia.

Setelah berakhirnya Orde Baru, ketika memasuki era reformasi di mana media massa menikmati kebebasannya dan tidak lagi menjadi corong bagi penguasa, akan tetapi tidak berarti dengan serta merta media massa terutama televisi bebas dari kontrol pihak tertentu. Meski tidak lagi menjadi corong penguasa akan tetapi media massa tidak pernah lepas dari intervensi sang pemilik modal yang dikuasai oleh segelintir orang yang notabene memiliki beragam kepentingan seperti kepentingan ekonomi, politik dan ideologi tertentu. Media massa yang ditumpangi kepentingan-kepentingan ini bisa diasumsikan sebagai salah satu pihak yang turut andil dalam konteks mengurangi rasa nasionalisme bangsa Indonesia.

McLuhan (1964:23-24) seorang pengkritik media, ia mengatakan media massa bukan hanya sebagai media pengirim pesan tapi juga mempengaruhi nilai-nilai budaya dan membuat sterotype mengenai gender, ras, dan etnik. Dan memiliki kontribusi terhadap pengalaman komunikasi dan bisa saja memonopoli dunia pemikiran seseorang.

Dalam perspektif industri budaya, "bahwa budaya populer adalah budaya yang lahir atas kehendak media massa" (Sunarti, 2003:23). Hal ini dianggap bahwa Media telah memproduksi segala macam jenis produk budaya populer yang dipengaruhi oleh budaya impor dan hasilnya telah disebarluaskan melalui jaringan global media hingga masyarakat tanpa sadar telah menyerapnya.

Berbagai macam gaya hidup telah direkonstruksi sedemikian rupa melalui beragam program acara media massa yang mencerminkan kebohongan publik itu, hingga pada akhirnya dapat menimbulkan suatu kebohongan tersembunyi dan tanpa sadar telah menjadi bagian dari realitas kehidupan yang sebenarnya. Suatu penanaman konsep ideologi ke dalam format acara melalui teks-teks media dan makna-makna yang ada di dalamnya serta 
praktik-praktik budaya telah melahirkan 'kesadaran palsu' di dalam persepsi pemirsa. Pola inilah yang menurut Adorno “... sebagai bentuk keberhasilan konspirasi perkawinan antara kapitalisme dengan budaya popular dalam memanpulasi kesadaran masyarakat dengan kesadaran semu. Bagi Adorno, kebudayaan industri merupakan satu bentuk dehumansasi lewat kebudayaan" (Graeme Burton, 2008:55).

Dilihat dari komposisi acaranya, media massa memiliki beberapa genre seperti program acara berita, film dan iklan komersial. Dari sisi berita, saat ini setelah runtuhnya rezim orde baru pada tahun 1998 membawa implikasi pada perubahan peran media massa atau pers secara signifikan sebagai penyampai informasi kepada publik. Nur Rachmaningtyas dalam Suhartoko (2012:82) mengatakan bahwa "Peran pers yang pada masa Orba seakan terkekang, melesat lepas begitu pemerintahan Orba jatuh oleh kuatnya gelombang reformasi. ... Ironisnya, keluarnya pers dari belenggu itu tidak selalu berimbas pada perbaikan kualitas jurnalis atau wartawannya. Sebaliknya, masa kebebasan pers justru membuka peluang sebagian wartawan untuk menyalahgunakan tugas jurnalistiknya ... Dalam praktiknya, pers diperankan dalam stigma bebas dan bertanggung jawab. Hanya, pertanggungjawaban itu bukan dipersembahkan kepada publik, tetapi lebih kepada penguasa."

Lebih lagi mengenai kekuatan pemberitaan pada media massa dalam memengaruhi publik, seperti yang juga diungkapkan oleh Rachmaningtyas dalam Suhartoko (2012:82) "Kekuatan media massa dalam memengaruhi opini publik saat ini juga terasa sangat ampuh. Lihatlah, betapa kuatnya magnet pemberitaan tentang seputar rencana kenaikan harga bahan bakar minyak (BBM). Aksi massa yang dimotori para mahasiswa dan diperkuat oleh sejumlah organisasi masyarakat (Ormas), serikat pekerja, terjadi di mana-mana, mulai kawasan ibu kota Jakarta dan serentak menyebar ke kota-kota lainnya, seperti Surabaya, Makassar, Medan, Bandung, Solo, Yogyakarta, bahkan di kota-kota kecil pun 'terprovokasi' oleh kekuatan media massa. Secara serentak mereka melawan kebijakan kenaikan harga BBM yang isunya mulai berlaku pada 1 April 2012." Terlihat bahwa media massa khususnya dalam genre berita di Indonesia cenderung ampuh dalam mempengaruhi dan menghegemoni khalayak.

Selanjutnya pada genre film yang ditayangkan media massa di Indonesia, membicarakan film saat ini tidak bisa terlepas dari proses penciptaan itu sendiri. Dengan kreatifitas tinggi media televisi memvisualisasikan tayangannya yang dikemas secara menakjubkan dalam alur dramatiknya sebuah cerita, telah mampu menghadirkan suatu realitas dunia maya, menjadi suatu realita baru yang seolah terlihat dalam kehidupan nyata. Itu semua karena peran media, bagaimana sebuah industri media menciptakan produknya dengan merekonstruksi nilai serta maknanya itu sedemikian rupa berdasarkan misi dari ideologi media tersebut hingga masyarakat tak berkutik dibuatnya. "Dibutuhkan cara dan tehnik untuk menyebarkan dan mempromosikan ideologi. Ideologi bisa disebarkan dengan paksaan dan kekuasaan..." (Ellul. 1973: 194).

Bagi Industri media televisi, tentunya sudah tidak asing lagi 
menciptakan perangkap acara yang di kemas secara menarik lewat beragam program acara dengan pengkonstruksian nilai dan maknanya serta dilancarkan secara terus-menerus dalam setiap serial komoditas, sehingga pemirsa begitu tergilagilanya mengikuti apa yang disuguhkan oleh industri media televisi yang pengaksesannya bisa dilakukan kapan saja dengan secara gratis itu. Hal inilah yang dikemukakan oleh Kaum Marxis “... nilainilai yang menguntungkan orang-orang yang menjalankan masyarakat, tentang ideide yang berkuasa sepanjang masa merupakan hasil dari ide orang yang berkuasa..." (John Storey, 2003:99).

Media massa khususnya televisi telah menjadi alat yang ampuh bagai jargon-jargon simbolik sebagai penarik untuk mempengaruhi alam pikiran serta pandangan masyarakat. Lewat media televisi dengan segala macam isi acaranya, maka 'gaya hidup' masyarakatpun dapat tercipta dengan sendirinya dan menerjang siapa saja yang ada didepannnya entah anak-anak, remaja maupun orang tua. Lihatlah ketika film heroik ala Amerika seperti Film Spiderman, Batman dan First Avenger diproduksi dan didistribusikan kesemua negara, maka segala macam pernik-pernik aksesoris seperti mainan dalam bentuk patung digandrungi olah anak-anak, demikian juga kaos gambar Spiderman yang sedang melayang di atas kota itu berada dalam dada anak-anak, remaja maupun orang tua menjalar dan beredar di jalan-jalan serta sudut mall maupun tempat lainnya. Ini artinya bahwa media dalam genre film memiliki hegemoni yang cenderung kuat menghegemoni masyarakat.
Selanjutnya dalam media massa dalam genre iklan komersial, jika dilihat dari efektifitas iklan dalam menyebarkan ideologi dominan bergantung pada pemanfaatan sistem citra yang ditanamkan sebagai strategi yang melibatkan artikulasi dari berbagai lapisan representasi ideologis. Bagaimana proses pemanfaatan teknis teknologi televisi menjadi medium penting penyampaian, dalam hal ini copywriter dan visualizer memainkan peran penting dalam menciptakan iklan yang kreatif dan tidak monoton.

Menurut Roesly dalam Dwi Ratna Aprilia, mengatakan bahwa "Kalau kita jeli sebenarnya iklan itu harus dipahami sebagai bagian dari beroperasinya mesin raksasa yang bernama kapitalisme, industri, dan akumulasi modal. Dengan kacamata seperti ini iklan bukan sekedar instrumen promosi atau soal jual beli. Iklan memiliki kekuatan ekspansi yang jauh lebih besar, dan tanpa tersadarkan iklan membentuk budaya konsumen (consumer culture) yang menjadi sendi utama pemasaran barang dan jasa. Akhirnya iklan pun menjadi bagian dari strategi dan rekayasa budaya yang mendasari kelangsungan hidupnya sistem ekonomi kapitalis. Singkatnya, iklan dibuat untuk merekayasa dan menciptakan secara terus menerus dan serempak kebutuhankebutuhan baru bagi konsumen." (Harry Roesli, dalam Dwi Ratna Aprilia, 2005:1).

Iklan televisi telah menghegemoni masyarakat untuk membeli produk-produk yang ditayangkan serta secara tidak langsung membangun budaya populer yang hanya berdasarkan kesenangan namun tidak substansial yaitu melepaskan kebosanan masyarakat dari aktivitas sehari-hari (Ben, Agger. 1992: 24) Iklan televisi yang ditayangkan cenderung mampu menarik 
perhatian masyarakat untuk mencoba bahkan audiens yang melihatnya berani mengeluarkan banyak uang untuk membeli produk yang diiklankan. Iklan yang ditayangkan televisi menjadi media komunikasi yang efektif menyebarkan ideologi, mempengaruhi khalayak umum untuk mempersepsikan peran sosial dan mengartikulasikannya dalam aktivitas hidup sehari-hari (hegemoni). Hal ini terlihat jelas dalam perilaku konsumtif masyarakat. Ketika menonton tayangan iklan timbul dalam bawah alam sadar pikiran penontonnya untuk mengingini dan membelinya karena dirasakan sangat membutuhkan. Iklan televisi memiliki semacam alat sensor yang dapat berupa menafsirkan dugaan, propaganda liris atau memberikan tuduhan terhadap produk tertentu yang layaknya pantas di iklankan.

Produk-produk yang di iklankan menjadi suatu malaikat penolong yang memberikan kemudahan dalam mengerjakan sesuatu serta memberikan kenyamanan bagi pembelinya. Produkproduk yang ditayangkan telah di rancang terlebih dahulu oleh para Copywriter dan Visualizer. Produk-produk yang di iklankan memberikan suatu citra baru seperti produk-produk minuman yaitu Cola-Cola, Pepsi serta produk rokok yaitu Marlboro, Gudang Garam serta banyak produk-produk lainnya. Citra baru ini dapat berupa suasana semangat baru yang dibangun pada momen tertentu lewat bahasa iklan yang puitis serta menyentuh.

Iklan memiliki daya kuat untuk menghegemoni khalayak umum dalam penanaman ideologi lewat bahasa iklan yang eksotik, sehingga dalam menyikapi hal tersebut dibutuhkan perlawanan dari diri konsumen sendiri dalam menilai apakah produk yang dibeli sungguh merupakah kebutuhan. Bukan hal yang mudah dalam melawan hegemoni iklan televisi karena ada suatu keinginan untuk membeli walaupun produk-produk yang dibeli belum tentu menjadi kebutuhan namun hanya menimbulkan suatu efek sublimasi pada diri sendiri.

Selanjutnya Gramsci dalam bahasan teorinya memberi solusi untuk melawan hegemoni (counter hegemony) dengan menitikberatkan pada sektor pendidikan. Kaum Intelektual menurut Gramsci memegang peranan penting di masyarakat. Berbeda dengan pemahaman kaum intelektual yang selama ini kita kenal, dalam catatan hariannya Gramsci(1971:100) menulis bahwa setiap orang sebenarnya adalah seorang intelektual namun tidak semua orang menjalankan fungsi intelektualnya di masyarakat. Counter hegemony Gramsci ini adalah upaya untuk mengimbangi dominasi dan hegemoni yang dikonstruksi oleh para kaum kapitalis dalam media massa.

Bila ditarik kesimpulan dari hasil temuan penelitian disampaikan sebelumnya, media memang masih memiliki kekuatan untuk menghegemoni namun pada iklan yang disajikan oleh peneliti didapatkan bahwa kekuatan hegemoni media dalam beberapa iklan yang ditampilkan kurang kuat dalam membangun rasa nasionalisme, karena mereka menganggap bahwa unsur nasionalisme hanya muncul di beberapa aspek. Dalam hal ini bisa dikatakan bahwa mereka mampu untuk melakukan counter hegemony, yaitu memberikan alternatif-alternatif pemaknaan terhadap wacana media. Jadi bisa dikatakan informan mendekati kesamaan pendapat bahwa secara umum hegemoni media 
cenderung kuat dalam aspek memperlemah rasa nasionalisme, media tidak menyajikan edukasi terhadap pemirsanya, yang ditampilkan hanyalah tentang hal-hal yang negatif yang membuat para pemirsa sulit untuk mengembangkan rasa nasionalisme.

\section{KESIMPULAN}

Berdasarkan data di lapangan yang kemudian didukung oleh konsep dan teori, terutama teori analisis resepsi, di mana penelitian ini salah satunya bertujuan untuk mengetahui makna dari informan terpilih terhadap fenomena iklan dengan topik nasionalisme Indonesia, yaitu salah satunya adalah Iklan Djarum versi Bull Race, Iklan You C1000 versi Miss Universe dan iklan Telkomsel versi Halmahera. Dapat ditarik kesimpulan:

a. Pemaknaan para informan terhadap fenomena iklan dengan topik nasionalisme Indonesia ternyata menempati pada posisi yang berbeda-beda. Mengacu pada Teori Analisis Resepsi Stuart Hall pemaknaan dikelompokkan dalam tiga posisi pemaknaan, yaitu secara Dominant-Hegemonic, Negotiated, dan Oposition.

b. Pemaknaan tersebut terjadi karena berbagai faktor, mulai dari faktor sosial, politik, budaya, ekonomi, maupun faktor historikal dari informan. Kecenderungan pemaknaan tersebut cukup kuat dari sisi historikal dan latar belakang pendidikan informan.

c. Walaupun ditemukan bahwa posisi pemaknaan informan terhadap iklan dengan topik nasionalisme itu beragam, namun semua informan cenderung sepakat bahwa kondisi nasionalisme saat ini mengalami pergeseran di era globalisasi, era keterbukaan informasi. Bukan berarti nasionalisme itu luntur, tetapi ketika teknologi itu dimanfaatkan untuk memperkuat kebersamaan antar sesama, itulah nasionalisme.

d. Pemahaman mengenai nasionalisme Indonesia bagi setiap informan dilatarbelakangi oleh gambaran mengenai Indonesia yang mereka terima dari suatu sistem yang hegemonik, pemaknaan mengenai gambaran-gambaran tentang Indonesia itu dipengaruhi oleh pengetahuan mereka pada zaman sekolah dulu.

e. Pemahaman mengenai nasionalisme Indonesia bagi setiap informan juga dilatar belakangi oleh faktor keluarga, melalui dialog-dialog mengenai Indonesia yang ditanamkan sejak dini oleh orang tua kepada anaknya.

f. Bisa dikatakan bahwa dari posisi pemaknaan informan mendekati kesamaan tipikal nasionalis pragmatis yang semu, karena memang dunia ini menciptakan kesemuan itu, realitasnya cenderung memunculkan kesemuan.

g. Kekuatan hegemoni media dalam hal ini kurang kuat dalam membangun rasa nasionalisme, karena nasionalisme hanya muncul beberapa aspek. Tetapi bisa dikatakan informan mendekati kesamaan pendapat bahwa hegemoni media cenderung kuat 
dalam aspek memperlemah rasa nasionalisme

Intinya bahwa setiap orang memiliki latar belakang kehidupan yang berbeda-beda, tetapi untuk kasus nasionalisme dalam iklan ini, hal yang paling kental mempengaruhi pandangan seseorang adalah sisi historikal khalayak. Bagaimana peran orang tua dan sekolah mereka itu berperan besar dalam menciptakan gambaran mengenai Indonesia.

Selanjutnya dari hasil penelitian menunjukkan bahwa dari posisi pemaknaan khalayak lebih banyak pada negotiated, di mana khayalak mampu untuk setuju dengan apa yang disampaikan oleh media dan juga mampu memberikan alternatif makna dari isi media. Kemudian juga dari hasil penelitian menunjukkan bahwa tipikal nasionalisme indonesia saat ini menempati tipikal nasionalisme civic-nationalism yang pragmatis, yang mengartikan nasionalisme dalam konteks yang luas, yaitu nasionalisme dari sisi kebersamaan.

Dan yang unik adalah, temuan dari penelitian ini adalah media yang selama ini dipandang memiliki kekuatan yang besar dalam mengubah pola pikir khalayak, tetapi pada konteks nasionalisme ini, hegemoni media tidak sekuat itu. Khalayak mampu melakukan counter hegemoni yaitu memiliki pandangan yang berbeda terhadap materi yang disampaikan oleh media.

Mengenai fenomena nasionalisme yang terjadi pada bangsa ini, peneliti memiliki beberapa saran untuk memperkuat rasa nasionalisme, yang perlu diperhatikan oleh pemerintah dan masyarakat saat ini adalah sejatinya, rasa nasionalisme itu bukanlah tumbuh dengan sendirinya, melainkan dipupuk dengan cara pendidikan dasar kita yang harus diperbaiki, dengan metode yang dulu ditemukan, seperti dulu kita dicekoki dengan mengikuti penataran P4, GBHN, menghafalkan UUD 45, menghafal Pancasila, juga hafal Pembukaan UUD, bahkan ditanya beberapa pasal pun juga hafal. Peneliti rasa model-model seperti itu yang harus diterapkan, yaitu mulai dari pendidikan. Yang menjadi masalah saat ini adalah pendidikan, SD, SMP, SMA, Perguruan Tinggi. Di kampus pun matakuliah pendidikan Pancasila hanya sebagai formalitas, kita bisa bayangkan bila itu benar-benar dikontrol oleh pemerintah, atau mungkin punya landasan pembelajaran, disesuaikan, ditetapkan dan diwajibkan seperti ujian negara, atau harus lulus dengan standar nilai itu yang bisa menumbuh-kembangkan nasionalisme saat ini. Sekarang ada istilah bela negara, wajib militer, sepertiSingapurawajib bela negara karena mungkin kebingungan pemerintah mengenai penerapan nasionalisme masyarakatnya, mungkin bela negara itu adalah solusi untuk menambahkan rasa nasionalisme. Peneliti lihat itu mungkin menjadi salah satu cara mudah untuk memperbaiki nasionalisme Singapura. Tapi untuk Indonesia ini mungkin bisa dimulai sedini mungkin dari aspek pendidikan.

\section{UCAPAN TERIMA KASIH}

Penulis mengucapkan terima kasih kepada Dr. Hendri Prasetyo, M.Si dan Dr. Endah Murwani M.Si selaku pembimbing yang telah memberikan waktu serta arahan. Kepada Bapak Rocky Prasetyo Jati, Bapak Irwan Jazir, Bapak Sony Suryono, dan Salman sebagai informan yang telah membantu peneliti dalam proses pengumpulan data. 


\section{DAFTAR PUSTAKA}

Agger, Ben. 1992. The Discourse of Domination: From the Frankfurt School to Postmodernism, Evanston, IL: Northwestern University Press

Baran, Stanley J \& Davis, Denis K. 2000. Mass Communication Theory, foundations, Ferment, and Future. Wadsworth Thomson Learning

Bungin, Burhan. 2001. Metodologi Penelitian Kualitatif. Jakarta: Rajawali Press.

Brooker, Will \& Jermyn, Deborah. 2003.

The Audience Studies Reader. London: Routlede

Burton, Graeme. 1999. Pengantar Untuk Memahami Media dan Budaya Populer. Yogyakarta: Jalasutra 2008. Pengantar untuk memahami Media dan Budaya Populer. Yogyakarta: Jalasutra.

Cordell, Karl. 2016. The Routledge Handbook of Ethnic Conflict. London: Routledge

Ellul, Jacques. 1973. Propaganda : The Formation of Mens Attitudes. New York: Vintage Books.

Fred, Wibowo. 2007. Kebudayaan Menggugat. Yogyakarta: Pinus Book Publisher

Frith, K.T. and Mueller, B. 2003. Advertising and Societies. New York: Peter Lang Publishing

Gramsci, Antonio. 1971. Selections from the Prison Notebooks, London: Lawrence and Wishart

Hall, Stuart. 1973, Encoding and Decoding In The Television Discourse. Birmingham: Univ.B'ham.,Centre for Contemp.Cult.Studs 1993. "Encoding, Decoding" dalam Simon During (Eds.). The
Cultural Studies Reader (2nd Eds.).

London: Routledge

Hariyono. 2014. Ideologi Pancasila, Roh Progresif Nasionalisme Indonesia. Jawa Timur: Intrans Publising.

Jeffrey Stout. 2004. Democracy and Tradition. New Jersey: Princeton University Press

Keating, Michael and McGarry, John. 2001. Minority Nationalism and The Changing International Order. New York: Oxford University Press

Lan, Thung Ju dan Manan, M. Azzam. (eds). 2011. Nasionalisme dan Ketahanan Budaya di Indonesia: Sebuah Tantangan. Jakarta: Obor Indonesia.

Lind, M. 1994. "In Defence of Liberal Nationalism", in Foreign Affairs.

LittleJohn, Stephen W. 2002. Theorities of Human Communication Seventh Edition. USA: Wadsworth Publishing Company

McLuhan. 1964. Understanding Media: Extension of Man. USA: A Signet Book.

Poerwandari. (2001). Pendekatan Kualitatif dalam Penelitian Psikologi. Jakarta : Lembaga Pengembangan Sarana Pengukuran dan Pendidikan Psikologi. FakultasPsikologi Universitas Indonesia.

Patton, Michael Quin. 2002. Qualitative Research and Evaluation Methods. Sage Publication (3rd ed).

Storey, John. 2003. Teori Budaya dan Budaya Pop Memetakan Lanskap Konseptual Cultural Studies. Yogyakarta: Qalam

Suhartoko dan Martadi. 2012. Pemuda dalam Pusaran Nasionalisme Semu. Surabaya: Kreasindo Publishing 
Sunarti, 2003. Popular Culture: Pengantar Menuju Budaya Populer. Yogyakarta: Jejak.

Supriadi, Yadi. 2013. Periklanan Perspektif Ekonomi Politik. Bandung:Simbiosa Rekatama Media.

\section{JURNAL}

Aprilia, Dwi Ratna. 2012. Jurnal Ilmu Komunikasi. Vol 1, No. 2, Juni 2005, Yogyakarta: Universitas Atma Jaya Yogyakarta
Hall, J. A. 1993. "Nationalism : CLassified and Explained", in Daudalus.

Rajiyem, dan Widodo Agus Setianto. 2004. Konstruksi Budaya dalam Iklan: Analisis Semiotik terhadap Konstuksi Budaya dalam Iklan Viva Mangir Beauty Lotion, Humaniora, Volume 16, No.2. Juni, Yogyakarta: Universitas Gadjah Mada. 
